\title{
DEVELOPING ENGLISH SPEAKING MATERIALS BASED ON CONTEXTUAL TEACHING AND LEARNING FOR GRADE TEN SENIOR HIGH SCHOOL AT SMA NEGERI 20 MEDAN
}

\author{
AN ARTICLE \\ Submitted in Partial Fulfillment of the Requirements \\ for the Degree of Sarjana Pendidikan
}

By:

Tiurmaida Silitonga

Registration Number: 2133321075

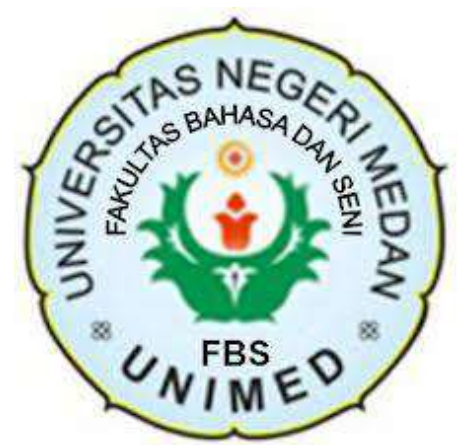

ENGLISH AND LITERATURE DEPARTMENT

FACULTY OF LANGUAGES AND ARTS STATE UNIVERSITY OF MEDAN 2018 
ARTIKEL

\section{DEVELOPING ENGLISH SPEAKING MATERIALS BASED ON \\ CONTEXTUAL TEACHING AND LEARNING \\ FOR GRADE TEN SENIOR HIGH SCHOOI}

AT SMA NEGERI 20 MEDAN

Disusun dan Diajukan oleh:

Tiurmaida Silitonga

Registration Number: 2133321075

Telah diverifikasi dan dinyatakan memenuhi syarat untuk diunggah pada jurnal online

Medan,

Oktober 2018

Menyetujui

Dosen Pembimbing 1

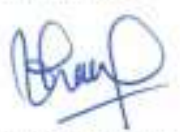

Prof. Dr. Sri Minda Murni, M.S. NIP. 196305251988032016
Dosen Pembimbing II

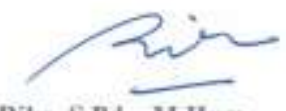

Rilca, S.Pd, M.Hum.

NIP. 197807172008122001

Ka. Program Studi Pendidikan Bahasa Inggris

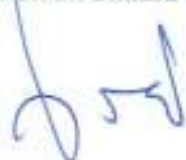

Nora Ronita Dewi, S.Pd., S.S., M.Hum. NIP. 198005222008122003 


\title{
DEVELOPING ENGLISH SPEAKINNG MATERIALS BASED ON CONTEXTUAL TEACHING AND LEARNING FOR GRADE TEN SENIOR HIGH SCHOOL AT SMA NEGERI 20 MEDAN \\ "Tiurmaida Silitonga \\ ${ }^{* *}$ Sri Minda Murni \\ ${ }^{* *}$ Rika
}

\begin{abstract}
Silitonga, Tiurmaida, 2133321075. Developing English Speaking Materials Based On Contextual Teaching And Learning For Grade Ten Senior High School At Sma Negeri 20 Medan. A Thesis, English and Literature Deparment, Faculty of Language and Arts, State University of Medan. 2018.

The objective of this study was to develop the speaking materials in Showing Care and Congratulation for the tenth grade students at SMA Negeri 20 Medan. The study was educational Research and Development (R \& D). The data were gathered by distributing questionnaires to 30 students of SMA Negeri 20 Medan and administering interviews to the teacher. The result of the study was a set of developed teaching speaking materials based on CTL entitled "Meet and Speak" Which consists of two chapters on the topic of (1) Don't be Sad My Friend and (2) Good Job. Each topic consists of Let's Remember, Let's Try, Let's Use, Let's Cooperate and Let's Share.
\end{abstract}

Keywords: Contextual Teaching and Learning, Supplementary, Speaking, RnD

* Graduate Status

${ }^{* *}$ Lecturer Status 


\section{INTRODUCTION}

\section{Background of The Study}

In this globalization era, English has an important role which brings many benefits to human life. English is very important in many situations, for example in technology, business and educational context. The importance of learning English become one of the significant reasons why English language is included as a lesson in the curriculum 2013.

Speaking skill in a new language is more difficult than other skills Nunan (2003:270). Moreover, as Indonesians who are not English speaker, the students will get difficulty to speak in English, because they are not accustomed in English. Teaching English needs good system in the field in order the education is going well and reaching the target determined. The main thing to teach English is development of curriculum in a country.

Based on the observation for the English teacher and the students on $6^{\text {th }}$ of March 2017 in SMA Negeri 20 Medan, they used "Buku Bahasa Inggris" published by Kemendikbud (Kementrian Pendidikan dan Kebudayaan Republik Indonesia) in 2014 there are some topics in the book but in this research the researcher only focus on two topics. They were Showing Care and Congratulation. According to syllabus grade ten of senior high school each materials were taught in the two meetings with the duration $4 \times 45$ minutes. But in the process of teaching and learning the teachers and students had limited speaking activity that caused the students were not able to speak English 
effectively. Even though the materials were available to be taught based on their life context.

In order solve to the problem, the writer conducted a research on designing speaking materials. The designed material was developed based on CTL to help the student to overcome their speaking problems. The purpose of the research is for designing speaking materials based on Contextual Teaching and Learning (CTL). CTL is an approach of teaching and learning that helps the teacher to relate subject materials to the real world situations and motivates the student to make connection between knowledge and its application to their daily life. Contextual Teaching and Learning is considered as the aspect in designing a set of instructional English speaking materials in this study. As stated by Tomlinson (2008) that helping learners to participate in meaningful communication in which they are using language to achieve intended outcomes is essential to the development of their communicative competence. The contextual teaching and learning (CTL) was applied in this research based on Crawford's procedures: Relating, experiencing, applying, cooperating, and transferring (REACT) (Crawford, 2001).

This research aimed to develop English Speaking Materials based on Contextual Teaching and Learning for the first semester of the tenth grade students of X SMA Negeri 20 Medan to help them improve their speaking skill. The concept of Contextual Teaching and Learning intended to create the meaningful English speaking learning process for the students. 


\section{REVIEW OF LITERATURE}

\section{The Nature of Speaking}

Speaking is a mean of communication. Speaking is so complex, because it includes many aspects such as grammar, pronunciation, fluency and vocabularies. . According to Nunan (2003: 48), speaking is a productive aural/oral skill. It involves the production of verbal utterance to grasp meaning. By gate states as cited by Louma (2004:104), the special features of speaking results from two sets of condition under which people speak: processing and reciprocity. Processing means that speaking involving action which simultaneously happens. Reciprocity means what a speaker says according to what his or her listener's reaction. On the other words, the speaker has to adapt and pay attention to his or her listener.

\section{Contextual Teaching Learning (CTL)}

Contextual materials help students connect the content they are learning to the life contexts in which the content can be used. Students then find meaning in the learning process. As they strive to attain learning objectives, they draw upon their previous experiences and build upon existing knowledge. By learning the subjects in an integrated, multidisciplinary manner and in appropriate contexts, they are able to use the acquired knowledge and skills in applicable contexts (Berns and Erickson, 2001). In a Contextual Teaching and Learning (CTL) students discover meaningful relationship between abstract ideas and practical applications in a real world context. The contextual teaching and learning (CTL) procedure applied in this research was based on Crawford's procedure: relating, experiencing, applying, cooperating, and transferring (REACT) (Crawford, 2001). REACT is described as follows :

1) Relating.

Relating is the heart of constructivism. It means that students ${ }^{\text {ee }}$ learning in the context of one's life experiences or preexisting knowledge (Crawford, 2001). Teachers relate when they link a new concept to something completely familiar to students, thus connecting what students already know to the new information. When the link is successful, students gain almost instant understanding.l 


\section{2) Experiencing.}

After the teacher connect the knowledge to their knowledge, students have to experience it before going further. Experiencing means learning by doing, through exploration, discovery, and invention. Students got knowledge based on their critical thinking through inquiry cycle.

3) Applying

Applying means by putting the concepts to use in the learning process. By doing this, students are expected to use the knowledge, information to their future life.

4) Cooperating .

Cooperating is the form of learning process by sharing the students knowledge to each other and gain some new information's in order to reach the learning process goal. Here, students are expected to develop their communicative skill. By listening to others in the group, students reevaluate and reformulate their own sense of understanding. They learn to value the opinions of others because sometimes a different strategy proves to be a better approach to the problem.

5) Transferring.

Transferring is a teaching strategy that defines as using information or knowledge in a new context which the context has not been covered in class. This activity helps students to get new learning experience.

\section{Materials Development}

Tomlinson states that materials development is everything made by people (the writers, the teachers, or the learners) to give and utilize information and provide experience of the use of language, which is designed to promote language learning. Before developing the materials the writer has to identify students ${ }^{\text {ee }}$ needs to consider the objective of the learning process. After that they can develop the materials by analyzing the studentse need and the objective in order to improve or to make them more suitable for learners ${ }^{\text {ee }}$ needs. 


\section{RESEARCH METHODOLOGY}

The research was conducted by using educational research and development ( $R$ \& D) method. $R$ \& $D$ is one of research design aims at developing and validating educational products, like curriculum, syllabus, textbooks, instructional media, modules, assessment instrument, etc. (Borg \& Gall, 2003).

This research was conducted by following six phases of R \& D:

1) Gathering information and data

2) Analyzing data

3) Designing new speaking materials

4) Validating new speaking materials

5) Revising new speaking materials

6) Revised-developing speaking materials (final product)

This study aimed to develop teaching and learning products for using in schools, in this case, students speaking learning materials. It was conducted to design English supplementary speaking materials based on contextual teaching and learning for high school students grade $\mathrm{X}$ on the first semester.

\section{Techniques of analysis Data}

The subjects of this research were the students in the first semester in the grade ten Senior High School at SMA Negeri 20 Medan. The data analyzed by getting the solution of the students 'problem and the appropriate English Speaking materials based on Contextual Teaching and Learning. The data was analyzed as follows: Analyzing students' needs by using questionnaire. The data was needed to evaluate the existing writing materials and analyze the students needs. Then the researcher developed the relevant speaking materials based on needs analysis. 


\section{Data Analysisis and Research Findings}

Data Analysis:

a. Need Analysis

\begin{tabular}{|c|c|}
\hline Aspects & Analysis \\
\hline Background & $\begin{array}{l}\text { From the question number } 1 \text { there were } 29 \text { or } 96,67 \% \\
\text { respondents who said that they have been learning English since } \\
\text { they elementary school. }\end{array}$ \\
\hline Necessities & $\begin{array}{l}\text { From the question number } 8 \text { there were } 16 \text { or } 53,33 \% \\
\text { respondents who said that they need supplementary materials } \\
\text { especially based on their contextual life. }\end{array}$ \\
\hline Lack & $\begin{array}{l}\text { From the question number } 13 \text { there were } 15 \text { or } 50 \% \text { respondents } \\
\text { who said that speaking materials could practice more and some } \\
\text { monologue activities. }\end{array}$ \\
\hline Wants & $\begin{array}{l}\text { From the question number } 6 \text { there were } 11 \text { or } 36,67 \% \\
\text { respondents who said that they were aware of the importance of } \\
\text { speaking skill and they feel the oral skill was more important for } \\
\text { them than the other skill. } \\
\text { From the question number } 7 \text { there were } 10 \text { or } 33,33 \% \\
\text { respondents who said that they were fluent speaking in English } \\
\text { with people around them. In order to reach the communicative } \\
\text { purpose in the communication, fluency is the important part to be } \\
\text { increased } \\
\text { From the question number } 14 \text { there were } 12 \text { or } 40 \% \text { respondents }\end{array}$ \\
\hline
\end{tabular}




\begin{tabular}{|c|c|}
\hline & $\begin{array}{l}\text { who said that they preferred to learn speaking in a group. From } \\
\text { the result, the researcher developed various speaking tasks for } \\
\text { groups activity such as groups discussion and groups } \\
\text { presentation. }\end{array}$ \\
\hline Goal & $\begin{array}{l}\text { From the question number } 2 \text { there were } 13 \text { or } 43,33 \% \\
\text { respondents who said that they students said that the teaching } \\
\text { learning process in the classroom, especially speaking, was not } \\
\text { interesting. } \\
\text { From the question number } 3 \text { there were } 21 \text { or } 70 \% \text { respondents } \\
\text { who said that speaking was important for their life } \\
\text { From the question number } 15 \text { there were } 14 \text { or } 46,67 \% \\
\text { respondents who said that the topics they have learned in } \\
\text { speaking class were very useful for their daily life. } \\
\text { From the question number } 16 \text { there were } 13 \text { or } 43,33 \% \\
\text { respondents who said that the module was not improving their } \\
\text { speaking ability. } \\
\text { From the question number } 17 \text { there were } 15 \text { or } 50 \% \text { respondents } \\
\text { who said that their textbook was not enough to measure their } \\
\text { speaking skill. }\end{array}$ \\
\hline Input & $\begin{array}{l}\text { From the question number } 4 \text { there were } 16 \text { or } 53,33 \% \\
\text { respondents who said that their previous topic was interesting. } \\
\text { This result helped the researcher in choosing the reference for the } \\
\text { developed materials books topic. }\end{array}$ \\
\hline
\end{tabular}




\begin{tabular}{|c|c|}
\hline & $\begin{array}{l}\text { From the question number } 5 \text { there were } 16 \text { or } 53,33 \% \\
\text { respondents who said that the materials used in the class were not } \\
\text { enhance them to develop their critical thinking. } \\
\text { From the question number } 9 \text { there were } 13 \text { or } 43,33 \% \\
\text { respondents who said that they preferred to learn speaking by } \\
\text { analyzing pictures with dialogue. } \\
\text { From the question number } 10 \text { there were } 14 \text { or } 46,67 \% \\
\text { respondents who said that the topic did not provide them with } \\
\text { new information. } \\
\text { From the question number } 11 \text { there were } 16 \text { or } 53,33 \% \\
\text { respondents who preferred to learn speaking in social life theme. } \\
\text { It proved that the students like the daily life topics in the } \\
\text { activity. } \\
\text { From the question number } 12 \text { there were } 23 \text { or } 76,67 \% \\
\text { respondents who said that they want pictures in speaking } \\
\text { anaterials. }\end{array}$ \\
\hline Role & $\begin{array}{l}\text { From the question number } 18 \text { there were } 15 \text { or } 50 \% \text { respondents } \\
\text { who said that the teacher needed to give more examples in the } \\
\text { classroom. } \\
\text { From the question number } 19 \text { there were } 18 \text { or } 60 \% \text { respondents } \\
\text { who said that they would find the answer from teacher and their } \\
\text { friend. }\end{array}$ \\
\hline stude & Fron \\
\hline
\end{tabular}




\begin{tabular}{|l|l|}
\hline who said that they would find the answer by discussing it with \\
the other students.
\end{tabular}

\section{Material Development}

The Framework of the Developed Materials

In developing the supplementary speaking materials based on contextual teaching and learning book, the researcher used many attractive fonts, different colours, pictures, interesting short functional texts and dialogues to make the students enjoy in the teaching and learning process. Supplementary speaking materials was made based on contextual teaching and learning book which used students contextual social daily life as the main theme of the book, and it helped the students in comprehending the expressions. The contextual teaching and learning (CTL) procedure applied in this research was based on Crawford's procedure: relating, experiencing, applying, cooperating, and transferring (REACT) (Crawford, 2001). REACT is described as follows :

\section{Let's Remember ( Relating)}

This stage is aimed to gain the students' previous knowledge and to activate the students' interest towards the next knowledge they will learn in the next activities. Relating is the heart of constructivism. It means that students' learning in the context of one's life experiences or preexisting knowledge (Crawford, 2001). Teachers relate when they link a new concept to something completely familiar to students, thus connecting what students already know to the new 
information. When the link is successful, students gain almost instant understanding.

\section{Let's Try (Experiencing)}

This stage aims to increase and test the students' understanding about the use of the expression. After the teacher connect the knowledge to their knowledge, students have to experience it before going further. Experiencing means learning by doing, through exploration, discovery, and invention. Students got knowledge based on their critical thinking through inquiry cycle.

3. Let's Use (Applying)

The activities in this stage aim to give students more vivid examples and model of the topics. By modelling and trying to remodelling the examples, it will be easier for students to understand the materials. Applying means byputting the concepts to use in the learning process. By doing this, students are expected to use the knowledge, information to their future life.

\section{Let's Cooperate (Cooperating)}

This stage is a production stage. Those activities aim to provide ways for students in developing their new knowledge. Cooperating is the form of learning process by sharing the students knowledge to each other and gain some new informations in order to reach the learning process goal. Here, students are expected to develop their communicative skill. By listening to others in the group, students reevaluate and reformulate their own sense of understanding. They learn to value the opinions of others because sometimes a different strategy proves to be a better approach to the problem. 
5. Let's Share (Transferring)

The activities in this section were concerning in their learning experience result. Transferring is a teaching strategy that defines as using information or knowledge in a new context which the context has not been covered in class. This activity helps students to get new learning experience.

There were three units in the book and it consisted of tasks in each unit.

1. Cover of the book

2. Content of the book

PREFACE

TABLE OF CONTENTS

CHAPTER

Let's Remember! (Relating)

Let's Try! (Experiencing)

Let's Use! (Applying)

Let's Cooperate! (Coperating)

Let's Share! (Transfering)

REFERENCESS 


\section{Material Validation}

The Score of Expert Judgment on English Speaking Materials

\begin{tabular}{|c|c|c|}
\hline Criteria of Validity & Maximum Score & Score \\
\hline Linguistic & $6 \times 5=30$ & 23 \\
\hline Process & $6 \times 5=30$ & 20 \\
\hline Content & $5 \times 5=25$ & $\mathbf{7 7}$ \\
\hline Layout & $2 \times 5=10$ & $\mathbf{9 5}$ \\
\hline Total & & \\
\hline Mean $: \mathbf{7 7 / 2 0}=\mathbf{3 . 8 5} ;$ Percentage 78/95 x 100\% $\mathbf{8 1 \%}$ \\
\hline
\end{tabular}

English Teacher's Validation Score

\begin{tabular}{|l|l|l|}
\hline Criteria of Validity & Maximum Score & Score \\
\hline Linguistic & $6 \times 5=30$ & 25 \\
\hline Process & $6 \times 5=30$ & 28 \\
\hline Content & $5 \times 5=25$ & 21 \\
\hline Layout & $2 \times 5=10$ & 9 \\
\hline Total & $\mathbf{9 5}$ & $\mathbf{8 3}$ \\
\hline \multicolumn{2}{|r}{ Mean : 4.15; Percentage: $\mathbf{8 3 / 9 5} \times \mathbf{1 0 0 \%}=\mathbf{8 7 . 3 \%}$} \\
\hline
\end{tabular}

The average score of the developed procedure texts materials for reading skill.

$$
\begin{aligned}
& \bar{X}=\frac{\text { First average score }+ \text { sceond average score }}{2} \\
& =\frac{3.85+4.15}{2}=4
\end{aligned}
$$


The average score of developed procedure text materials for reading skill from two the experts is 4. It is categorized "Good" since the mean is within the interval $3.40<\bar{X} \leq 4.19$. Based on the result, the developed procedure text materials are suitable and appropriate contextual teaching and learning speaking materials for the tenth grade students of Senior High School.

\section{Revision and Final Product}

Revision of Product

\begin{tabular}{|c|c|c|}
\hline Point of the Unit & Point to Revise & Revision \\
\hline \multicolumn{3}{|c|}{ (Don't be sad my friend) } \\
\hline Chapter 1 & & \\
\hline The Unit's Title & $\begin{array}{l}\text { Add exclamation mark in } \\
\text { the end of the title } \\
\text { chapter } 1\end{array}$ & $\begin{array}{l}\text { Added exclamation mark } \\
\text { at the end of the title } \\
\text { chapter } 1\end{array}$ \\
\hline Task 1 & Change the text & The text is changed \\
\hline Task 2 & Change the task & The task is changed \\
\hline Task 3 & No Revisions & No Revisions \\
\hline Task 4 & Change the task & The task is changed \\
\hline Task 5 & No Revisions & No Revisions \\
\hline Task 6 & Change the task & The task is changed \\
\hline Task 7 & No Revisions & No Revisions \\
\hline Task 8 & Change the task & The task is changed \\
\hline Task 9 & No Revisions & No Revisions \\
\hline
\end{tabular}




\begin{tabular}{|l|l|l|}
\hline Task 10 & No Revisions & No Revisions \\
\hline \multicolumn{1}{|l|}{ The Unit's Title } & \multicolumn{1}{|c|}{ Good Job! } & At the end of the title \\
& & chapter 2 \\
\hline Task 1 & Grammatical mistakes & Changed the instruction \\
\hline Task 2 & instruction & \\
\hline Task 3 & Change the task & The task is changed \\
\hline Task 4 & No Revisions & No Revisions \\
\hline Task 5 & Add guided activity & Guided activity is added \\
\hline Task 6 & Add guided activity & Guided activity is added \\
\hline Task 7 & Change the task & The task is changed \\
\hline Task 8 & No Revisions & No Revisions \\
\hline Task 9 10 & Change the task & The task is changed \\
\hline & No Revisions & No Revisions \\
\hline & & \\
\hline
\end{tabular}

\section{CONCLUSION AND SUGGESTIONS}

\section{Conclusion}

This study was aimed to developed a set of teaching speaking materials by considering the students' needs and teacher's needs. After analyzing the data, it was found that the students grade ten of senior high school at SMA Negeri 20 Medan need a supplementary speaking materials. Hence, a set of teaching 
materials was designed as supplementary speaking materials for gradeten at SMA Negeri 20 Medan. The development of speaking materials, contained of two chapters on the topic of (1) Don't be Sad My Friend and (2) Good Job. It is consist of Let's Remember, Let's Try, Let's Use, Let's Cooperate and Let's Share.

\section{Suggestions}

\section{The English Teacher}

This supplementary English speaking book can be used as the materials to teach the students in the teaching and learning process. The materials developed in the book are aimed to improve students speaking skill. Teachers can use contextual based speaking book to teach some expressions in English used in daily life. The teachers should explain the students about what they are going to learn in each unit. Moreover, the teachers can gain students interest and attention by giving good examples in the learning process by using attractive media and exciting learning method.

\section{Material Developers}

The contextual teaching and learning based supplementary speaking book was developed for tenth grade. By conducting the needs analysis, the material developers could know the needs and interests of the students in order to make it relevant. Interesting theme, attractive learning media, various activities, and colorful design could make the supplementary speaking materials fresh and make the students enjoy in improving their speaking skill. The material developers 
should improve the supplementary speaking materials more attractive and interesting in order to maintain the students attention in learning speaking skill

\section{REFERENCES}

Berns, R. \& Erickson, P. 2001. Contextual teaching and learning: Preparing students for the new economy. Washington: National Academy Press.

Crawford, L. M. 2001. Teaching contextually: Research, rationale, and techniques for improving student motivation and achievement. Texas: CCI Publishing, Inc.

Luoma, S. 2004. Assessing Speaking. Cambridge: Cambridge University Press.

Nunan, D. 2003. Practical English Language Teaching. New York: McGraw Hill Contemporary.

Nurefendi. 2015. Developing English Supplementary Speaking Materials For The Tenth Grade Students Of Senior High Schools. Medan : State University of Medan.

Tomlinson, B. 2008. Developing Materials for Language Teaching. Bloomsbury. Cambridge: Cambridge University Press.

Wahyuni, Elli Setio. 2013. Implementing Contextual Teaching and Learning in Speaking to the First Semester Student of Business Administration in Hang Tuah University. Graduated paper of Hang Tuah University. Unpublished. 